\title{
EKS TAPOL PKI DAN KONTROL PEMERINTAH\& Studi pada Komunitas Tapol PKI Moncongloe Sulawesi Selatan (1979-2003)
}

\author{
THE EX-POLITICAL PRISONERS OF INDONESIAN COMMUNIST PARTY (PKI) \\ AND THE GOVERNMENT CONTROL: \\ Study on Community of Political Prisoner of PKI in South Sulawesi Moncongloe \\ $1979-2003$
}

\section{Taufik Ahmad}

Balai Pelestarian Nilai Budaya Makassar e-mail: taufik_mukarrama@yahoo.com

Naskah Diterima: 18 Juni $2013 \quad$ Naskah Direvisi: 19 Juli $2013 \quad$ Naskah Disetujui: 1 Agustus 2013

\begin{abstract}
Abstrak
Penelitian ini bertujuan menjelaskan kontrol pemerintah dan politik resistensi tahanan politik Partai Komunis Indonesia (PKI) pasca pembebasan dengan mengambil kasus pada komunitas tahanan politik Moncongloe di Sulawesi Selatan. Metode yang dipergunakan adalah metode sejarah, dengan tahap; pengumpulan sumber (heuristik), kritik sumber mencakup kritik eksteren yang menyangkut otentisitas atau keabsahan sumber dan kritik interen yang menyangkut kredibilitas atau bisa tidaknya sumber dipercaya, interpretasi atau penafsiran atas data, dan yang terakhir adalah penyajian kisah sejarah atau historiografi. Hasil penelitian menunjukkan bahwa pasca pembebasan, persoalan komunitas tahanan politik Moncongloe tidak berakhir. Mereka dihadapkan pada kontrol pemerintah melalui perangkat konstitusi dan penjurusan negatif pada diri tahanan politik sebagai orang "tidak bersih lingkungan". Akibatnya, melahirkan sebuah komunitas yang terpinggirkan dalam bidang sosial, politik dan ekonomi. Setelah reformasi, ruang perjuangan eks tahanan politik mulai terbuka lebar dengan berdirinya berbagai organisasi-organisasi yang memperjuangkan hak-hak mereka yang selama ini diabaikan oleh pemerintah.
\end{abstract}

Kata Kunci: tahanan politik, kontrol pemerintah, Moncongloe, Sulawesi Selatan.

\begin{abstract}
This study aims to explain the control of the government and political resistance performed by post-released prisoners of Partai Komunis Indonesia (PKI). This is a case study of the Moncongloe community of political prisoners in South Sulawesi. The author conducted history method, covering heuristics (collecting sources), source criticism (including external criticism concerning the authenticity or validity of sources as well as internal criticism regarding the credibility of the sources, and interpretation of the data), and historiography (the presentation the story). The results showed that the issue of Moncongloe political prisoners has not come to an end even though they have already been released. The post-released prisoners are facing the government control through the constitution and negative image on political prisoners as not having "clean environment". As a result, they are socially, politically and economically marginalized. After the reform, they had a wide opportunity to struggle because there were many organizations established to fight for the rights of those who have been ignored by the government.
\end{abstract}

Keywords: political prisoners, government control, Moncongloe, South Sulawesi. 


\section{A.PENDAHULUAN}

Seorang ditangkap, ditahan, diadili kemudian dihukum adalah hal yang wajar terjadi dalam suatu negeri yang menganut prinsip-prinsip rule of law. Akan tetapi persoalan menjadi lain ketika seorang ditangkap, dipenjara, lalu dipisahkan dari lingkungan sosialnya, hanya karena perbedaan berpikir dan gagasan. Kondisi inilah yang dialami oleh tapol PKI di Sulawesi Selatan. Mereka ditangkap dan diasingkan di Moncongloe tanpa pernah melalui proses pengadilan. ${ }^{1}$ Secara bertahap kemudian mereka dibebaskan, lalu dinyatakan tidak bersalah.

Masa pengasingan mereka berakhir tahun 1979, tidak berarti persoalan hidup mereka selesai, tidak pula berarti bahwa kembali ke masyarakat dan seluruh hak sosial-politik mereka dikembalikan seperti semula. Mereka tetap memikul berbagai "hukuman kolektif". Justru kehidupan mereka lebih berat.Kalau dikucilkan dalam kamp pengasingan itu menjadi hal lazim dalam penjara-penjara di negeri manapun di dunia, tetapi dikucilkan ditengah kehidupan sosial masyarakat akan mengarah pada depresi dan kehilangan kepercayaan diri. Kehidupan eks tapol pada periode ini ibarat hidup dalam penjara sosial (Ahmad, 2009: 205).

Komunitas tapol Moncongloe merupakan produk dari kebijakan pemerintaha Orde Baru di Sulawesi Selatan. Sejak Oktober 1965 sampai Maret 1966, jumlah tahanan politik meningkat dengan cepat mencapai 9.765 orang untuk wilayah Sulawesi Selatan (Ahmad, 2012: 156). Akibatnya penjara-penjara dipenuhi tapol sehingga memerlukan biaya yang cukup besar, sementara anggaran negara tidak mengalokasikan untuk tapol. Oleh karena itu, Kodam XIV Hasanuddin dalam hal ini Team Pemeriksa Daerah (Teperda)

\footnotetext{
${ }^{1}$ Terdapat 911 orang Tapol yang diasingkan di Moncongloe, Sulawesi Selatan. Mereka umumnya aktivis berasal dari organisasi BTI, Lekra, CGMI dan Gerwani. Pada tahun 1979 mereka dibebaskan, namun tetap mendapat kontrol dari Negara.
}

Sulawesi Selatan dan Tenggara membuka kamp pengasingan di Moncongloe. Kebijakan ini dimaksudkan untuk mengurangi beban anggaran negara dengan memberi kesempatan kepada tapol untuk bercocok tanam. Pada tahun 1979, keseluruhan tapol di bebaskan dan dikembalikan ke masyarakat. Setelah pembebasan justru mereka mendapat perlakukan buruk dengan dilabelkan sebagai orang tidak bersih lingkungan sehingga mereka tidak mendapatkan akses ekonomi dan politik.

Tiga pokok persoalan yang akan dijawab dalam artikel ini, yaitu pertama, bagaimana proses pembebasan komunitas tapol PKI Moncongloe Sulawesi Selatan? Kedua, bagaimana strategi bertahan eks tapol di tengah stigma buruk yang dilabelkan kepada mereka sebagai orang bersih lingkungan? Dan ketiga, bagaimana perjuangan komunitas tapol Moncongloe menuntut rehabilitasi di era reformasi? Oleh karena itu, artikel ini dimaksudkan untuk menjelaskan kehidupan tapol setelah mereka dibebaakan dan dikembalikan ke masyarakat, yang meliputi, menjelaskan proses penyelesaian komunitas tapol, menjelaskan strategi bertahan komunitas tapol setelah dibebaskan, dan menjelaskan perjuangan tapol menuntut rehabilitasi di era reformasi.

Komunitas tapol Moncongloe adalah suatu komunitas yang diciptakan oleh pemerintah Orde Baru. Komunitas ini merupakan produk dari sebuah kebijakan pemerintah Orde Baru dengan ciri khas periodenya adalah kontrol yang berlapis dan instrumen kekerasan secara struktural. Oleh karena itu pendekatan teoritis yang digunakan dalam penelitian ini, yaitu teori hegemoni negara yang diperkernalkan oleh Antonio Gramsci. Konsep hegemoni Gramsci dapat dilihat melalui penjelasannya tentang basis dari supremasi kelas yang menunjukkan bahwa suatu kelompok dan anggotanya menjalankan kekuasaan terhadap kelompok-kelompok sosial di bawahnya dengan dua cara, yaitu kekerasan dan persuasi (Simon, 2004: 19). 
Cara kekerasan (represif) yang dilakukan kelas atas terhadap kelas bawah disebut dengan tindakan dominasi, sedangkan cara persuasinya disebut dengan hegemoni. Perantara tindak dominasi ini dilakukan oleh para aparatur negara seperti polisi, tentara, dan hakim, sedangkan hegemoni dilakukan dalam bentuk menanamkan ideologi untuk menguasai kelas atau lapisan masyarakat di bawahnya. Dalam konteks ini, sejarah komunitas tapol Moncongloe dapat dilihat dari pendekatan Gramsci. Pemerintah Orde Baru menciptakan label kepada tapol sebagai orang tidak bersih lingkungan untuk mengontrol dan memperkuat hegemoni.

\section{B. METODE PENELITIAN}

Beranjak dari pemikiran teoritis di atas, metode sejarah kritis yang digunakan dalam penelitian ini melalui tahapan heuristik, kritis sumber, interpretasi dan historiografi. Sumber-sumber primer yang digunakan meliputi, arsip dan dokumen pemerintah dan pribadi serta wawancara mendalam. Selain sumber primer, informasi tentang tapol juga diperoleh melalui melacak karya-karya terdahulu, berupa buku, artikel, majalah atau bulletin dan lain sebagainya. Sumber-sumber sejarah tersebut, setelah melalui proses kritik selanjutnya dinarasikan dalam bentuk eksplanasi sejarah.

\section{HASIL DAN BAHASAN \\ 1. Penyelesaian Tapol Moncongloe}

Sejak 1 Desember 1975 pemerintah Indonesia melaksanakan janji pembebasan tapol untuk Golongan B dan dikembalikan masyarakat sebanyak 1.309 orang terdiri atas 1.003 sipil dan 306 bekas anggota ABRI dengan pangkat Bintara. Satu tahun berikutnya dibebaskan lagi sekitar 2.500 orang di seluruh Indonesia (Fealy, 1995: 29). Di Moncongloe, pembebasan tapol untuk Golongan B dilakukan mulai tahun 1975-1977. Jumlah tapol yang dibebaskan di Moncongloe untuk golongan B mencapai 466 orang, dan untuk golongan C 403 orang, kemudian terdapat 42 orang dikirim ke Nanga-nangan pada tahun 1978 (Anwar Abbas, wawancara 20 Juli 2008).

Prioritas pertama yang dibebaskan adalah tapol yang sudah berusia 60 tahun, tapol yang menderita sakit kronis, cacat mental dan fisik. Mereka yang akan dibebaskan melakukan persiapanpersiapan, mengemasi barang-barang dan melakukan kunjungan-kunjungan ke barak lain. Kebiasaan ini dilakukan untuk memberi kesempatan kepada tapol yang masih ditahan apabila ingin menitip surat kepada keluarganya. Kesibukan berjalan tidak seperti biasanya saat pengumuman tapol yang akan dibebaskan. Beban kerja sedikit dikurangi, dan aturan-aturan mulai melunak. Tapol diberi kesempatan mengikuti olah raga pada hari Rabu, sepak bola, badminton, dan tenis meja.

Pembebasan tapol khusus di Kamp Inrehab Moncongloe sampai juga kepada masyarakat setempat sekitar Moncongloe. Ada sejumlah rombongan kecil sekitar puluhan orang penduduk mendatangai kamp. Inrehab, mereka langsung menuju ke barak, karena penjagaan pos sudah dilonggarkan. Penduduk memberi ucapan selamat kepada tapol yang tidak lama lagi akan dibebaskan. Suasana haru terjadi diantara penduduk dengan tapol, beberapa di antaranya memberikan bantuan berupa makanan sebagai bekal. Penduduk yang tidak sempat masuk dalam Kamp Inrehab, hanya berdiri di pinggir jalan menunggu tapol lewat dan kemudian mengucapkan salam perpisahan dengan melambaikan tangan. Rasa haru bercampur sedih dialami tapol dan penduduk mengisi ruang hati mereka masing-masing. Penduduk setempat merasa kehilangan teman yang sering membantu bekerja di kebun. Hubungan tapol dengan penduduk setempat memang berjalan dengan baik, walau pada awalnya ada semacam ketakutan terhadap tapol sebagai akibat image yang dibentuk oleh petugas bahwa PKI itu kejam. Hubungan yang baik itu terlihat ketika beberapa tapol tidak bersedia meninggalkan Moncongloe, bahkan ada beberapa tapol menikah 
dengan penduduk setempat setelah pembebasan. Di antara mereka yang menikah adalah Ir. Rasjidi Amra (tapol dari Mandar) menikah dengan Sumiati (putri seorang petugas), Sumiran (tapol dari Instansi Polisi Perhubungan Makassar) menikah dengan seorang guru di Moncongloe.

Pemerintah mempunyai sejumlah persyaratan dalam hal pembebasan tapol golongan B, di antaranya kadar ideologi, kedudukan dalam organisasi, kelakuan selama di tempat pengasingan, serta kondisi fisik dan umur bersangkutan. Kadar ideologi merupakan suatu hal yang sulit untuk diukur, sehingga menurut tapol kadang tidak sesuai dengan yang sebenarnya. Oleh petugas Inrehab, tapol yang dianggap masih membahayakan negara dibawah ke Nanga-nangan Kendari. Ini digambarkan oleh Brigjen TNI $\mathrm{H}$. Sukma E Panglima Kodam XIV Hasanuddin kepada Muh. Tahir tapol dari Selayar. Sebenarnya Muh. Tahir dimasukkan daftar untuk dibawah ke Nanga-nangan, tetapi ia meminta kepada panglima Kodam XIV Hasanuddin untuk mempertimbangkannya permohonan untuk kembali ke Selayar. Brigjen H. Sukama E, mengabulkan permohonan tersebut dengan satu syarat tidak melakukan perkumpulan di Selayar, tidak bertemu dengan temantemannya sesama tapol, tidak menyebarkan ajaran komunis. (Muh. Tahir, waancara, 25 Agustus 2008)

Pada 18 Desember 1977 tim dari POMDAM/Teperda Sulawesi Selatan dan Tenggara mengunjungi Moncongloe untuk mendata tahanan yang akan dibebaskan. Data yang mereka butuhkan seperti asal daerah dan tempat tujuan tapol saat dibebaskan, melakukan memotretan terhadap tapol, melengkapi riwayat hidup tapol serta berbagai kelengkapan administrasi yang dibutuhkan. Pendataan ini dilakukan sebelum tapol dibebaskan. Pada malam hari tanggal 19 Desember 1977 tapol diberangkatkan ke Kodim 1408 Makassar untuk bermalam. Pada keesokan harinya tapol diberangkatkan secara berkelompok ke Kantor Corps Polisi Militer Kodam XIV Hasanuddin untuk diadakan upacara pembebasan, dengan berjalan kaki dengan kode jalan yang dilalui Jln. Jend. A. Yani, Jln. Jend. Sudirman, Jln. Irian. Khusus tapol yang berdomisili di Makassar, selesai upacara kembali ke Kodim 1408 Makassar untuk menerima uang ongkos ke tempat rumah masing-masing. (Ahmad, 2009: 232) Kemudian tapol di daerah, keesokan harinya kembali ke daerah asal masingmasing. Tidak semua tapol mendapat ongkos pulang, karena ada beberapa kasus hanya mendapat ongkos setelah menjual kebun dan singkongnya kepada petugas.

Upacara resmi pembebasan tapol Golongan B berlangsung di POMDAM XIV Hasanuddin pada tanggal 20 Desember 1977. Upacara pembebasan itu dihadiri sekitar 466 tapol Golongan yang berasal dari berbagai tempat di Sulawesi Selatan dan Tenggara. Secara yuridis, pembebasan dilakuan dengan berdasarkan dua surat keputusan, yakni pertama, Surat Keputusan Komando Operasi Pemulihan Keamanan dan Ketertiban Nomor: SKEP25/KOPKAM/XII/1977 tentang pengembalian 10.000 orang tahanan $G 30$ S/PKI Gol. B ke masyarakat. Upacara pembebasan dipimpin oleh Big. Jen. TNI Kusnadi mewakili Pangdam XIV Hasanuddin atas nama Laksamana TNI Sudomo selaku Komando Operasi Pemulihan dan Keamanan.

Sementara tapol Moncongloe yang tidak dipulangkan karena faktor "kadar ideologi" dikirim ke Nanga-nangan Sulawesi Tenggara. Jumlah tapol dibawah ke Nanga-nangan sebanyak 42 orang (Ahmad, 2009: 229). Biaya pemberangkan ke Nanga-nangan ditanggung sepenuhnya oleh Teperda. Mereka juga dibekali alatalat pertanian seperti cangkul, parang, mesin diesel untuk penerangan. Setiba di Nanga-nangan, para tapol ditempatkan di rumah-rumah yang telah disiapkan. Beberapa rumah telah terisi oleh tapol dari daerah Sulawesi Tenggara. Kondisinya hampir sama dengan Kam. Inrehab 
Moncongloe. Tapol dari Moncongloe langsung ditempatkan pada rumah-rumah yang telah disiapkan.

Akhir tahun 1977, tahanan politik militer yang selama ini ditahan di RTM dibawah ke Moncongloe. Tapol militer ini berjumlah $30 \mathrm{kk}$. Mereka menempati rumah-rumah yang telah disediakan. Saat kedatangan tapol dari militer, di Moncongloe sudah tidak ada tapol yang berasal dari sipil, namun barak, gereja, masjid, aula dan pos jaga masih ada saat itu. Kemudian seluruh fasilitas kamp Inrehab sudah lapuk sebagian juga diruntuhkan oleh tentara. Kecuali masjid dan gereja yang masih berdiri dan dipergunakan sampai sekarang.

Tahun 1978, adalah tahun pertama Kamp. Inrehab Moncongloe dalam keadaan sunyi. Barak-barak telah kosong, di dapur hanya ada beberapa kucing liar yang pernah dipelihara tapol, atau kucing yang lolos dari makanan tapol. Pos jaga yang berada di tempat agak tinggi itu juga kosong. Tidak ada lagi suara hentakan dan tembakan yang kadang-kadang diperdengarkan petugas kepada tapol. Sekarang lokasi kamp. Inrehab telah menjadi areal perkebunan. Demikian pula kebun-kebun yang telah dibuka oleh tapol, sebagian tidak terawat dan ada pula digarap oleh pekerja kebun milik tentara. Khusus lokasi kamp. Inrehab sekarang dikuasi dan dimiliki oleh seorang purnawirawan militer. Namun pengelolaannya dilakukan oleh seorang eks tapol dari tahanan politik militer.

\section{Tapol dalam Arus Stigma}

Setelah tapol dibebaskan, tidak berarti kondisi fisik dan psikologis tapol kembali seperti semula. Eks tapol umumnya lanjut usia ketika dibebaskan dari tempat pengasingan Moncongloe. Mereka nyaris tidak memiliki harta benda lagi. Walaupun tidak terlibat dalam kegiatan PKI, mereka tetap dipecat dari tempat kerjanya tanpa ada uang pesangon. Belum lagi keluarga mereka yang tercerai berai, siksaan, penyakit malaria, asma, lever, bronchitis, mata rabun, tuli, cacat fisik dan gila adalah yang mereka terima sebagai kenyataan hidup (Ahmad, 2009: 230). Diperparah lagi dengan trauma berkepanjangan, ketidakpercayaan diri dan susah mempercayai orang lain atau penuh rasa curiga. Diperlukan waktu yang cukup lama untuk menyesuaikan diri dengan lingkungannya. Itu bukan perkara mudah, apalagi dengan status sebagai eks tapol yang harus menerima stigmatisasi orang tidak "bersih lingkungan" yang dilakukan secara intensif oleh pemerintah Orde Baru - Eks tapol yang dikembalikan ke masyarakat diwajibkan melaporkan kepada lurah/kepala desa satu kali dalam satu minggu. Kewajiban yang dibebankan kepada tapol ini dimaksudkan sebagai pengawasan kepada tapol. Berdasarkan sifatnya, pengawasan dilakukan dengan berbagai cara; yaitu secara menyeluruh kepada warga masyarakat, dalam hal ini diadakan pendekatan tertentu di bidang pengadministrasian penduduk. Kemudian, secara khusus kepada tapol bersangkutan, baik secara aktif maupun pasif. Unsurunsur yang melaksanakan pengawasan yaitu pemerintah daerah termasuk RW/RK/RT, POLRI dan LAKSUS. Kegiatan pengawasan ini dilakukan untuk memperkecil ruang gerak eks tapol di dalam masyarakat sehingga fungsi dan perannya dapat diminimalkan sampai adanya jaminan masyarakat tidak tercemar dengan pikiran-pikiran komunis. Tampaknya, sampai tapol dibebaskan, masih tertanam dalam pemikiran aparat pemerintah bahwa eks tapol itu "tidak bersih lingkungan" sehingga segala gerakgeriknya harus diawasi demi keamanan dan ketertiban. (Arsip Muhammad Saleh Lahade Reg. 41)

Dalam memperkuat hegemoni, pemerintah Orde Baru mewajibkan eks tapol untuk mengikuti "bimbingan" atau penataran khusus yang dilaksanakan oleh Provinsi Daerah Tingkat I Sulawesi Selatan. (Arsip Kotamadya Ujung Pandang Reg. 935). Penataran ini dimaksudkan untuk menghapus pengaruh ideologi 
komunis yang dianggap sebagai bahaya laten. Gelombang pertama penataran dilaksanakan pada tanggal 27-31 Desember 1979 terdiri atas 90 orang eks tapol, kemudian Gelombang kedua dilaksanakan tanggal 15-19 Januari 1980 terdiri atas 80 orang eks tapol, menyusul gelombang-gelombang berikutnya, sehingga semua eks tapol golongan B mengikuti penataran tersebut. Penataran dilaksanakan di Hotel Raya Makassar. Materi penataran meliputi pemahaman dan pengalaman Pancasila serta UUD 1945.

Orde Baru juga membuat berbagai ketentuan yang membatasi ruang gerak bagi mereka yang ditapolkan. Setiap warga negara Indonesia yang hendak melamar pekerjaan, mengurus sekolah, naik pangkat atau jabatan, diharuskan memiliki "surat keterangan tidak terlibat G 30 S/PKI". Surat keterangan yang diperlakukan Kopkamtib sejak akhir tahun 1960-an itu adalah yang bersangkutan tidak terlibat dalam percobaan kudeta 1965 maupun pernah menjadi anggota PKI atau organisasi-organisasi yang memiliki hubungan dengan PKI. Pemakaian "surat keterangan bebas G 30 S/PKI" itu menurut pemerintah disempurnakan berlandaskan pertimbagan-pertimbagan sistem pengawasan untuk mencegah "bahaya Komunis" di Indonesia. Untuk membendung pemikiran-pemikiran komunis maka dilakukan kontrol kepada orang-orang yang pernah menjadi anggota PKI dengan tidak memberi dia peran sosial politik dalam masyarakat. Sehingga seakan terjadi pembunuhan karakter setiap tapol yang telah dibebaskan.

Pemerintah Orde Baru juga mengeluarkan aturan diskriminatif terhadap tapol menyangkut izin bepergian. Tidak seperti warga lain, bekas tapol diwajibkan membawa surat izin bepergian bila hendak melakukan perjalanan dari kota tempat kediaman ke kota lain. Surat tersebut merinci aturan-aturan yang tidak boleh dilanggar oleh bekas tapol bersangkutan. Pemegang surat hanya diperbolehkan meninggalkan kota kediamannya selama 15 hari saja. Ketika sampai di tempat tujuan, eks tapol harus melapor terlebih dahulu ke kantor pemerintah setempat. Kemudian ketika kembali ke kota asal harus melapor lagi kepada kantor yang mengeluarkan izin perjalanan. Dalam jangka tiga bulan surat tersebut tidak dipergunakan maka tidak berlaku lagi (Krisnadi, 2000: 195)

Perlakuan diskriminatif Orde Baru terhadap eks Tapol bukan saja pengingkaran terhadap HAM, tapi sudah merupakan bentuk penghukuman tanpa batas (Krisnadi, 2000: 196). Dengan alasan pengawasan, pemerintah memberlakukan pencantuman kode tertentu pada Kartu Tanda Peduduk (KTP) mantan tapol. Tindakan Orde Baru ini, sadar atau tidak sadar telah membuat diskriminasi terhadap warga negaranya. Mantan tapol memang diharuskan memiliki KTP yang berbeda dengan warga negara Indonesia lainnya karena ditambah kode ET (Eks Tahanan Politik). Hal ini merupakan suatu mekanisme yang tepat dalam pengontrol eks tapol. Segala kegiatan kemasyarakatan, mulai dari pindah rumah, pernikahan, surat-surat izin lainnya biasanya dimulai dengan menunjukkan KTP. Dengan KTP yang dimiliki mantan tapol yang ditelah diberi kode ET, setiap mantan tapol harus mendapatkan "Surat Keterangan Tidak Terlibat dalam G 30 S/PKI", kalau yang bersangkutan hendak melamar suatu pekerjaan. Mustahil mendapat surat tersebut, karena stigma tambahan telah dicantumkan dalam KTP-nya dengan kode ET. Bukan hanya bekas tapol yang menerima perlakuan diskriminatif, tetapi juga anak sampai cucu mereka.

Pemberlakukan kode ET pada KTP eks tapol bermula dari instruksi yang dikeluarkan oleh menteri dalam negeri No. 32 Tahun 1981 yang ditujukan kepada gubernur dan kepala daerah di seluruh Indonesia, dilengkapi dengan pedoman pelaksanan No. 188.52-36009 tanggal 22 Agustus 1981 tentang pembinaan dan pengawasan bekas tahanan G 30 S/PKI. Instruksi tersebut menyatakan bahwa bekas 
tapol dilarang menjadi anggora partai politik atau Golkar, organisasi masyarakat atau organisasi keagamaan, guru, dan dosen, pendeta atau khatib, dalang, lurah pengacara, dan wartawan. Kedudukan dalam profesi tersebut dikhawatirkan pemerintah dapat dimanfaatkan oleh eks untuk mempengaruhi masyarakat atau mengembangkan ideologi komunis. Untuk memudahkan pengawasan terhadap tapol, berdasarkan intruksi tersebut maka KTP tapok diberi kode ET. Dalam pelaksanaannya, tidak hanya KTP eks tapol yang diberi kode ET, tetapi terkadang keluarga, atau anak saudara juga terkena (Krisnadi, 2000: 187).

Pelarangan terhadap tapol tidak hanya pada kegiatan-kegiatan politik, mendirikan organisasi, atau bergabung dengan organisasi tertentu tetapi juga menyangkut aktivitas pribadi mereka diluar ikatan-ikatan dengan organiasi tertentu. Misalnya, larangan kepada eks tapol untuk membuat tulisan-tulisan di surat kabar harian atau majalah-majalah. (Arsip Kotamadya Ujung Pandang, Reg. 942) Demikian pula setiap tapol tidak diperbolehkan menjadi guru atau ada larangan mengajar bagi eks tapol, temasuk golongan C-2 dam C-3. (Arsip Kotamadya Ujung Pandang, Reg. 944) Pengawasan pemerintah Orde Baru ternyata tidak hanya pada aktivitas eks tapol dalam berorganisasi, tetapi juga menyangkut pada kehidupan pribadi eks tapol secara khusus.

Tapol tidak mempunyai hak pilih atau dipilih dalam pemilu. Ketentuan itu diatur dalam pasal 2 Undang-Undang No. 15 Tahun 1969, tentang pencabutan hak pilih dan hak memilih bagi eks tapol organisasi terlarang dalam pemilihan umum.(Lembaran Negara Republik Indonesia, 1969, No. 61) Menjelang pemilu tahun 1977, aturan tersebut mulai agak sedikit "diperlonggar". (Krisnadi, 2000: 199) Pemerintah menetapkan bahwa eks tapol Golongan C, mereka yang tidak terlibat atau diduga tidak terlibat secara langsung dalam "G $30 \mathrm{~S}$ " (Golongan $\mathrm{C}-1$, C-2, C-3), dapat menggunakan serta diberi hak untuk memilih. Sedangkan pegawai negeri yang terlibat dalam G $30 \mathrm{~S}$ dan dipertimbangkan penggunaan hak pilihnya adalah pegawai negeri sipil Golonga C-1 yang saat diselenggarakannya daftar pemilihan umum bekerja pada instansi pemerintah. Akan tetapi lembaga pemilihan umum menyatakan bahwa penggunaan hak pilih bagi eks tapol, kendatipun telah mendapat mengesahan, dapat saja dibatalkan atas pertimbangan keamanan. Seluruh eks tapol Golongan B tidak boleh memilih dan dipilih. Sampai tahun 1977, seluruh eks tapol golongan B dan $\mathrm{C}$ tidak diberi hak untuk dipilih sebagai anggota legislatif.

Pada hakikatnya, bukan hanya eks tapol yang merasakan diskriminasi dari pemerintah Orde Baru, tetapi telah menyentuh sampai pada keluarganya. "Istilah bersih diri" dan "bersih lingkungan" yang tersebar pada tahun 1980-an merupakan tafsiran masyarakat atas petunjuk pelaksanaan "skrining mental ideologis" yang dikeluarkan oleh Menteri Dalam Negeri pada tahun 1982. Selain keterlibatan seorang dengan "G 30 S/PKI" skrining juga dilakukan pada lingkungan keluarganya, persaudaran, pergaulan yang dominan atau sangat berpengaruh pada sikap, perilaku dan mental ideologi seseorang. Yang dikategorikan lingkungan dominan adalah orang tua terhadap anakanaknya, mertua terhadap menantu, nenek terhadap cucu yang diasuh, atau paman, kakak, orang lain yang pernah membiayai kehidupan anak atau seseorang, pernah menanam budi, menolong dalam waktu relatif lama, dan sebagainya. Bisa juga suami terhadap istri atau sebaliknya, bahkan lingkungan pergaulan.

Data hasil skrining dimasukkan dalam berkas yang disebut "sampul D'. Data dikumpulkan dari bebagai komando militer setempat, para pejabat pemerintah dan polisi tanpa sepengetahuan yang bersangkutan. Catatan "tidak bersih" dalam sampul D membuat seseorang tidak mungkin lagi masuk menjadi anggota ABRI atau mendapat pekerjaan dalam 
instansi pemerintah atau Badan Usaha Milik Negara. Skrining diperlakukan juga bagi guru, anggota parpol dan Golkar, pers, dalang, lurah, petugas lembaga bantuan hukum, dan ulama. Skrining sangat efektif tidak saja memergoki bekas tapol dan keluarganya yang berupaya menjual tenaga untuk mendapatkan pekerjaan di bidang-bidang yang dinyatakan tertutup bagi mereka, tetapi juga membuka kesempatan kepada perusahaan-perusahaan yang tidak "vital" untuk membeli tenaga mereka di bawah upah minimum. Eks tapol pun menerima peruntungannya, dengan dasar daripada tidak mendapatkan pekerjaan sama sekali.

Ketidakberdayaan tapol setelah dibebaskan karena tidak adanya aset ekonomi yang bisa dikelola. Sementara lapangan kerja untuk seorang tapol sangat susah, baik bagi tapol itu sendiri maupun keluarganya. Anak-anak mereka tidak dapat melanjutkan pendidikan secara maksimal karena selalu dikaitkan dengan PKI. Suatu kasus misalnya, sebagian besar anak-anak dari Desa Tabaringan Takalar tidak dapat menempuh pendidikan tinggi, karena baginya kuliah hanya membuang waktu dan uang karena selepas kuliah pun juga tidak bisa bekerja. Hampir seluruh penduduk Desa Tabaringan dinyatakan terlibat dengan $\mathrm{G} 30 \mathrm{~S}$, sehingga berimbas kepada anak-anak mereka. Karena tekanan dari pemerintah dalam bidang ini sehingga sebagian besar tapol memilih bekerja sebagai buruh bangunan, berpindah-pindah dari satu tempat ke tempat lain. Pekerjaan sebagai buruh ternyata memiliki hikmah buat mereka. Terkadang, ketika ada proyek_pembangunan yang membutuhkan tenaga kerja dengan jumlah cukup besar, mereka saling memanggil dan terjadi reuni di tempat pekerjaan tersebut. Akhirnya terjalin ikatan solidaritas diantara mereka. Mereka bersama-sama di penjara, kemudian di bawah ke Inrehab Moncongloe, sekarang dipertemukan dengan suasana masih dalam tekanan pemerintah Orde Baru.
Tekanan dan perlakuan diskrimatif yang dialami oleh eks tapol menimbulkan rasa frustasi. Mereka sedikit melakukan aksi sebagai resistensi inheren dari kondisi diskriminatif itu dengan melakukan tindakan-tindakan manipulatif terhadap identitasnya. Anwar Abbas misalnya, saat dibebaskan, karena jenuh dengan kegiatan melapor kepada pemerintah setempat memilih kabur ke tempat-tempat tidak terjangkau. Misalnya menjadi tahun-tahun awal pembebasannya lebih memilih menjadi tukan kebun, dimana dia dapat terhindar dari wajib lapor, dan tidak terlalu dipusingkan stigma yang membuatnya terkucil dari masyarakat. Ir. Rasyidi Amra, dengan keahliannya dalam bidang arsitektur melakukan kegiatan sebagai konsultan pada proyek-proyek pemerintah. Berkat bantuan sahabat dekatnya dia dapat menutupi identitas sebagai eks tapol. (Ir. Rasjidi Amra, wawancara, 23 Agustus 2009).

Eks tapol yang tidak sanggup bertahan memilih meninggalkan daerah Sulawesi Selatan. Mereka merantau untuk melepaskan beban dan stigma yang melekat pada dirinya sebagai orang yang "tidak bersih lingkungan". Cak Gun salah seorang tapol, pada saat pembebasan langsung meninggalkan Makassar tanpa ada tujuan yang jelas. Selama bertahuntahun Cak Gun hanya pindah dari satu tempat ke tempat yang lain, sampai kenyataan hidupnya sebagai eks dapat diterima dengan lapang. Upaya lain yang dilakukan oleh tapol dengan menutup diri mereka, menyembunyikan identitasnya agar orang-orang sekelilingnya tidak mengetahui latar historisnya. Ada beberapa tapol dari daerah memilih menetap di Kota Makassar daripada kembali ke daerah asalnya untuk mengais rejeki, mereka hidup di rumah-rumah kontrakan, kolom rumah, tanpa ada jaminan hari tua. Padahal sebelum peristiwa G $30 \mathrm{~S}$, mereka termasuk orang-orang sukses, terhormat di lingkungannya dan berdedikasi terhadap profesinya. 
Hampir semua aktivitas yang berhubungan dengan administrasi selalu disertakan syarat tidak terkait dengan $\mathrm{G} 30$ S/PKI. Mulai dari Surat lamaran kerja, menjadi pegawai negeri sipil, ABRI, POLRI, pindah domisili, sampai pada persoalan pernikahan terkadang mendapat tekanan dari pemerintah. Kekerasan struktural berupa peraturan yang diskriminatif itu tidak hanya tertuju kepada mantan tapol korban Tragedi 65/66 tetapi juga terhadap anak dan cucu mereka atau keturunan mereka. Salah seorang eks tapol bernama Kasman Suparlan, ketika bebas bermaksud untuk menikah kembali, karena pada saat di Inrehab. Moncongloe istrinya minta diceraikan. Akan tetapi karena statusnya sebagai eks tapol PKI maka menghadapi berbagai macam kendala, mulai dari pengurusan administrasi sampai pada persoalan penghulu yang akan menikahkan sangat sulit didapat. Ini merupakan salah satu contoh dari ribuan kasus yang dialami oleh eks tapol.

Perlakuan terhadap eks tapol, mulai memberi kode ET pada KTP, pembatasan terhadap akses pemberoleh pekerjaan, ketentuan wajib lapor, sampai pada urusan pernikahan pun mendapat tekanan. Perlakuan yang demikian telah mengabaikan martabat sebagai manusia dan melanggar HAM. Hak-hak sipil dan politik mereka telah dirampas oleh pemerintah. Tidak hanya itu stigma yang terbentuk di dalam masyarakat sebagai orang sesat menyingkirkan mereka dari lingkungan sosialnya. Memang stabilitas sebagai syarat mutlak kelangsungan pembangunan, tetapi tidak harus ditukar dengan merampas hak-hak sipil dan politik warga tertentu.

Diskriminasi yang ditujukan kepada tapol mengakibatkan komunitas tapol Moncongloe termarjinalkan di semua lapangan kehidupan. Salah satu persoalan utama dihadapi tapol Moncongloe pasca pembebasan adalah sulitnya mencari lapangan kerja. Sebagian besar dari mereka bekerja sebagai buruh bangunan. Mereka umumnya bermukin di pinggir Kota Makassar.

\section{Perjuangan Rehabilitasi}

Era reformasi ditandai dengan terus dilakukannya pembenahan di bidang hukum serta dijalankannya pemberantasan KKN dirasa masih belum maksimal dengan belum dijalankannya salah satu agenda penting, yakni penyelesaian secara menyeluruh berbagai kasus pelanggaran Hak Asasi Manusia (HAM) masa lalu, utamanya peristiwa 1965 hingga kini masih belum menentukan titik terang, atau bahkan ditelantarkan (Kompas, 2 Mei 2005). Padahal, penyelesaian secara tuntas masalah pelanggaran HAM masa lalu amat penting untuk segera dilakukan, mengingat cakupan peristiwa baik luas dan jumlah korban serta melibatkan segmen masyarakat yang sangat besar. Penyelesaian kasus ini akan membawa pada usaha rekonsiliasi yang memang sangat dibutuhkan mengingat adanya kecenderung disintegrasi bangsa kian mengkhawatirkan.

Setelah keruntuhan rezim Orde Baru, harapan akan terwujudnya keadilan bagi para korban pelanggaran HAM masa lalu seolah menemukan titik terang kearah penyelesaian. Karena selama lebih dari tiga dekade Orde Baru, situasi politik yang represif-autoritarian tidak memungkinkan para korban untuk memperjuankan apalagi memperoleh keadilan yang dicitakan. Dunia peradilan di era Orde Baru begitu terkooptasi oleh kekuasaan. Pers terbelenggu dan terbatasi oleh berbagai produk hukum yang bukannya fasilitatif, namun justeru mengekang, sementara parlemen hanya merupakan kepanjangtanganan kekuasaan. Kini, dengan adanya keterbukaan dan demokratisasi, pengungkapan berbagai kasus pelanggaran HAM masa lalu yang menjadi aspirasi masyarakat terkhusus para korban peristiwa 1965 seolah menemukan momen tepat untuk segera dilaksanakan. Penyelesaian masalah pelanggaran HAM masa lalu adalah mendesak untuk 
dilaksanakan jika Indonesia masih berkomitmen sebagai negara demokrasi (Arinanto, 2003: 280).

Penyelesaian kasus pelanggaran HAM peristiwa 1965 mendesak untuk segera dilaksanakan, dengan beberapa alasan Pertama, dapat dikatakan bahwa Indonesia kini masih berada pada masa peralihan/transisi dari periode otoriter ke rezim yang (lebih) demokratik. Masa peralihan adalah masa yang strategis, momen paling tepat untuk menyelesaikan kasus pelanggaran HAM. Penyelesaian kasus masa lalu mempunyai misi penting untuk mencegah impunitas atau kekebalan dari para pelanggar HAM. Kesan bahwa para pelanggar HAM bisa bebas meninggalkan korbannya tanpa pertanggungjawaban tentu saja merupakan sesuatu yang sangat kontras dengan nilainilai keadilan dan cita-cita negara hukum. Penetapan kesalahan terhadap pelaku penting agar doktrin equality before the law dalam negara hukum yang juga merupakan norma internasional dalam Universal Declaration of Human Rights (UDHR) tidak hanya menjadi sekedar mitos. Demikian pula penuntasan kasus pelanggaran HAM masa lalu dengan memberikan keadilan dan pemulihan hak bagi para korban adalah hak setiap orang yang dilanggar hak dasarnya, pemberian keadilan bagi para korban juga syarat mutlak tercapainya rekonsiliasi nasional.

Rekonsiliasi atau perdamaian atau persahabatan baru akan mungkin terwujud, jika pelaku telah ditetapkan sebagai pihak yang bersalah dan menjalani hukuman (atau kewajiban lain menurut hukum), dan pihak korban mendapatkan kompensasi, restitusi, rehabilitasi, dan pemulihan nama baik. Tanpa adanya pengungkapan dan penetapan siapa yang salah dan bertanggung jawab dan kewajiban bagi pelaku (apakah untuk menjalani hukuman, meminta maaf dan atau memberi ganti rugi) akan sangat sukar dapat tercipta perdamaian dan persahabatan (Adam, 2005). Pada tingkat lebih sederhana, permintaan maaf yang pernah dilontarkan
KH. Abddurrahman Wahid sebagai tokoh NU, walau tidak memberi dampak psikologis yang signifikan tetapi telah memulai sesuatu yang segar bagi para korban peristiwa 1965.

Pernyataan K.H. Abdurrahman Wahid tersebut ditanggapi secara positif bagi mereka yang termasuk korban peritiwa 1965. Pada tanggal 10 Januari 2001, Samaun Utomo mendirikan suatu organisasi yang diberi nama Lembaga Perjuangan Rehabilitasi Pegawai Negeri Korban Rezim Orba. Lembaga ini bertujuan untuk memperjuangkan rehabilitasi bagi para pegawai negeri sipil yang diberhentikan karena dianggap terlibat dalam G 30 S. Meskipun kemudian tidak terbukti atas keterlibatannya, tetapi mereka tidak mendapatkan hak-haknya sebagai pegawai negeri sipil. Pada tanggal 20 Oktober 2002, lembaga ini mengalami perubahan nama yakni Lembaga Perjuangan Rehabilitasi Korban Rezim Orde Baru (LPR-KROB). Dengan perubahan ini, maka cakupan peruangan lembaga ini tidak hanya ditujukan pegawai negeri sipil tetapi seluruh korban peristiwa 1965.

Pada tahun itu juga, dibentuk cabang dari LPR-KROB di Sulawesi Selatan dengan susunan pengurus; Ir. Rasjidi Amra (ketua), M.S. Baharuddin (Wakil Ketua I), Sunar I.S, (Wakil Ketua II), Parinsen Sommen (Sekretaris), Muhammad Jufri Buape (wakil sekretaris I), Sarmanto Sarmo (wakil Sekretaris II), Samet S. (Bendara I) Sri Soetyowati (Bendahara II), Sunar I.S, Munis, dan Lamaeda (Biro Organisasi), Achmad Gazali, Samun Gaddong, Muhammad Jufri Buape (Biro Penerangan), Anwar Abbas, M.S. Baharuddin (Biro Data dan Dokumentasi), Mawardi Y.S, Rahma, U.S, Rahmat (Biro Sosial Ekonomi).

Pada dasarnya, sebelum lembaga ini didirikan telah terjalin ikatan-ikatan emosional yang cukup solid diantara sesama eks tapol dalam bentuk kekerabatan dan kekeluargaan. Kontakkontak dengan mereka tetap terjalin 
dengan baik walaupun mereka tidak terpisah sejak dibebaskan dari Moncongloe. Ada semacam kegelisahan yang dialami oleh beberapa eks tapol dengan memikirkan nasib teman-teman mereka setelah pembebasan. Satu persatu telah tiada, dan usia semakin senja sehingga ada kekhawatiran sejarah mereka dihilangkan tanpa jejak. Kondisi ini disadari oleh Anwar Abbas sehingga melakukan inisiatif mempertemukan teman-teman mereka sesama eks tapol di Sulawesi Selatan dan Tenggara. Pertemuan-pertemuan mereka inilah yang kemudian menjadi cikal bakal terbentuknya organisasi perjuangan rehabilitasi korban 1965 di Sulawesi Selatan.

Selain LPR-KROB terdapat organisasi lain, antara lain Lembaga Penelitian Korban Peristiwa 65 (LPKP) dan Paguyuba Korban Orde Baru (PAKORBA). LPKP bertujuan untuk memperjuangkan rehabilitasi dan konpensasi bagi mereka korban tragedi 1965, sedangkan PAKORBA tidak terbatas pada korban tragedi 65 saja, tetapi semua peristiwa-peristiwa pelanggaran HAM lainnya selama pemerintahan Orde Baru. Strategi perjuangan mereka umumnya dilakukan dengan cara-cara konstitusional, yaitu melakukan upaya-upaya hukum, perjuangan penghapus produk undangudang Orde Baru yang diskriminatif, menerbitkan bulletin-bulletin, majalah, dan melakukan kerjasama dengan berbagai lembaga-lembaga yang terkait didalamnya. LPR-KROB sejauh ini telah melakukan kerjasama dengan Lembaga Bantuan Hukum (LBH), YLBHI, KONRTRAS, KOMNAS HAM, Syarikat Yogyakarta, Organisasi anak muda NU di daerahdaerah, LSM serta partai/orgnisasi massa lainnya. (Warta LPR-KROB, Mei, Juni, Juli 2007) Disamping juga menggalaang kerjasama dengan organisasi sesama korban peristiwa September 1965. Langkah ini sebagai sikap untuk menjaga persatuan diantara korban peristiwa September 1965.
Sampai akhir tahun 2003 perjuangan korban peristiwa G 30 S 1965 belum mencapai hasil yang diinginkan, namun perjuangan tersebut telah menunjukkan kemajuan, misalnya adanya surat dari Mahkamah Konsitusi kepada Presiden, Surat Dewan Perwakilan Rakyat kepada presiden, surat KOMNAS HAM kepada presiden. Pada pokoknya semua surat tersebut memberikan informasi kepada presiden bahwa secara hukum korban belum pernah dinyatakan bersalah, oleh sebab itu diharapkan presiden memberikan keputusannya atas pemohonan rehabilitasi korban. (Poi Kromo, 2008) Menanggapi perjuangan para korban tragegi 1965, pemerintah kemudian meluncurkan Rancangan Undang-Undang Komisi Kebenaran dan Rekonsiasi (RUU-KKR).

Reaksi pemerintah terhadap upaya merealisasikan kasus pelanggaran HAM tahun 1965 cukup walaupun terkesan agak terlambat dan hati-hati. Presiden Susilo Bambang Yudoyono mempunyai kemauan politik untuk menyelesaikan kasus pelanggaran HAM yang terjadi pada masa lalu dengan meningkatkan Sekretaris Kabinet Sudi Silalahi mengenai implementasi Undang-Undang Komisi Kebenaran dan Rehabilitasi. Secara konkret presiden Yudoyono berkeinginan untuk merehabilitasi dan memberikan kompensasi kepada tahanan politik yang ditahan di pulau Buru (Kompas, 17 Maret 2005). Keinginan politik presiden itu ditanggapi oleh organisasi-organisasi perjuangan korban tragedi 1965 di Sulawesi Selatan dengan mengeluarkan pernyataan-pernyataan yang pada intinya bahwa tahanan politik tidak hanya ada di Pulau Buru, tetapi kondisi yang kurang lebih sama yang dialami oleh tahanantahanan politik lain di seluruh Indonesia, termasuk di Kamp. Inrehab Moncongloe Sulawesi Selatan.

Berdasarkan kondisi demikian, maka DPC LPR-KROB Sulawesi Selatan bersurat ke Komnas HAM .untuk mempertanyakan sekaligus menjelaskan tentang Kamp. Inrehab Moncongloe 
sebagai salah satu tempat pengasingan tahanan politik PKI. Menyusul kemudian lembaga ini mengirim data dan penjelasan situasi Kamp. Inrehab secara detail disertai jumlah tahanan politik yang ditempatkan di sana. Dari perjuangan ini, maka masalah tapol Moncongloe telah menjadi agenda Komnas HAM. Perkembangan berikutnya, untuk mencapai rekonsiliasi dan rehabilitas serta pemberian kompensasi kepada korban tragedi 1965 dibutuhkan saksi, pelaku dan korban, atau harus ada buktibukti otentik sehingga seseorang dapat mendapatkan rehabilitasi dan kompensasi dari pemerintah.

Persoalan yang mengemuka kemudian, bagaimana menghadirkan saksi atau korban tanpa ada pelindungan hukum yang jelas. Untuk mengantisipasi ketidakjelasan saksi atau keengganan seseorang bersaksi karena alasan keamanan, dibentuk organisasi yang diberi nama Lembaga Perlindungan Saksi dan Korban, yang sebelumnya telah disahkan Undang-Undang Nomor 13 Tahun 2006 tentang Perlindungan Saksi dan Korban. UU PSK secara tegas menyatakan bahwa LPSK adalah lembaga yang mandiri, atau biasa disebut komisi independen. UU PSK ini sebenarnya memandatkan untuk dibuat 2 (dua) buah Peraturan Pemerintah (PP), yaitu PP tentang Pemberian Kompensasi dan Restitusi dan PP tentang kelayakan, jangka waktu dan besaran biaya bantuan kepada korban dan saksi. Namun oleh Dephukham, kedua mandat pembentukan tersebut akhirnya digabung menjadi satu PP, yaitu PP No. 44 tahun 2008. Tujuan PP ini adalah memberikan kompensasi, restitusi dan bantuan kepada saksi dan korban.

Dalam PP tersebut dijelaskan pula syarat-syarat permohonan kompensasi, yaitu harus melampirkan indentitas pelaku pelanggaran HAM yang berat dan harus melampirkan putusan yang sudah berkekuatan hukum tetap. Persyaratan sangat sulit dipenuhi oleh sebagian besar tapol PKI yang pernah diasingkan di Moncongloe. Kenyataannya, banyak korban yang sudah tidak mengenal pasti identitas pelaku. Situasi pada saat tragedi 1965, secara psikologis mereka tertekan ditambah sulitnya mengidentifikasi secara personal pelaku, karena sebagian besar dilakukan oleh organisasi massa. Kemudian mereka dibawah ke Moncongloe sebagai tahanan politik merupakan proyek insititusi negara. Kemudian sebagian besar putusan-putusan berkenaan dengan mereka, seperti surat pemberhentian sebagai pegawi negeri sipil karena terindikasi dengan G 30 S mereka musnahkan setelah pembebasan untuk menghilangkan jejak mereka karena trauma yang berat. Dengan sulitnya persyaratan yang harus ditempuh korban untuk mengajukan permohonan kompensasi dan bantuan, maka semakin sulit pula korban mendapatkan hak-haknya dan hal itu berarti tanggung jawab negara pun menjadi hilang.

Semakin terbengkalainya pengusutan dan pengungkapan pelanggaran HAM masa lalu tentu akan membawa dampak yang tidak baik jika tidak sesegera mungkin dilakukan langkah-langkah menuju ke arah penyelesaian. Impunitas, atau kekebalan akan menjadi terlembagakan. Sebagaimana hukum pidana telah mengingatkan, sanksi keras akan menjadi penjera dan pencela bagi pelaku sekaligus peringatan bagi pihak lain untuk tidak melakukan kejahatan serupa. Tidak dilakukannya penuntutan dan pengungkapan serta pemberian sanksi terhadap kejahatan HAM masa lalu akan menjadi inspirasi mereka yang kuat dan berkuasa untuk menggunakan cara apa saja termasuk melanggar HAM demi kekalnya kekuasaan yang dimilikinya.

\section{PENUTUP}

Pembebasan tapol mengakibatkan politik pengontrolan negara terhadap tapol berubah dari kontrol fisik oleh militer dalam kamp Inrehab ke kontrol sosial terhadap komunitas tapol di tengah lingkungan masyarakat. Untuk memperkuat hegemoninya, pemerintah 
mengeluarkan berbagai ketentuan yang membatasi dan mengontrol secara efektif ruang gerak eks tapol. Kontrol sosial negara tersebut mengarah pada pembentukan identitas eks tapol sebagai komunitas "tidak bersih lingkungan", sehingga ruang eks tapol untuk mengembangkan dirinya tertutup di setiap bidang kehidupan. Identitas eks tapol kemudian menjadi stigma yang dikonsumsi oleh masyarakat sebagai sesuatu yang benar sehingga melahirkan kebencian dan ketakutan terhadap eks tapol. Lebih parah lagi, stigma terhadap eks tapol tersebut menjalar sampai anak dan cucu mereka sehingga melahirkan suatu bentuk pengasingan baru di tengah lingkungan masyarakat secara berganda. Sebuah pengasingan yang mengakibatkan hilangnya hak-hak sipil dan politik, jauh lebih menyiksa daripada pengasingan di kamp pengasingan yang memang terisolasi. Untuk bertahan di tengah arus stigma itu, eks tapol terkadang berkamuflase, menyembunyikan identitas dengan merubah nama, dan berpindahpindah dari satu tempat ke tempat lain.

Pergantian rezim Orde Baru ke era reformasi membawa perubahan bagi eks tapol di berbagai tempat di Indonesia. Era reformasi yang pengarah pada proses demokrasi nampaknya memberi perubahan terhadap komunitas eks tapol untuk membuka diri dengan mendirikan organisasi-organisasi yang bertujuan untuk memperjuangkan hak-hak sipil dan politik mereka. Organisasi tersebut antara lain, Lembaga Penelitian Korban Peristiwa 65 (LPKP 65) Lembaga Pejuangan Rehabilitasi Korban Rezim Orde Baru (LP-KROB), dan Paguyuban Korban Rezim Orde Baru. Organisasi-organisasi ini secara intensif melakukan perjuangan menuntut rekonsiliasi, rehabilitas dan kompensasi.

\section{DAFTAR SUMBER}

\section{Arsip}

Arsip Muhammad Saleh Lahade Reg. 41.

Arsip Kotamadya Ujung PandangReg. 935, 942, 944.

Lembaran Negara Republik Indonesia Tahun 1969 No. 61.

\section{Buku dan Artikel}

Adam, Asvi Warman, 2004.

"Gerakan 30 September 1965:

Pengungkap Pelaku dan Korban" dalam Warta DPP LPR-KROB Th III OktoberNovember-Desember, 2004 2005.

Reparasi Masa Lalu, Jawa Pos, 18 Juli.

Ahmad, Taufik. 2009.

Kamp. Pengasingan Moncongloe.

Jakarta: Desantara. 2012

"South Sulawesi: The Military, Prison Camps and Forced Labour" dalam Douglas Kammen dan Katherine McGregor (Ed) The Contours of Mass Violence in Indonesia 1965-68, Singapore, NUS Press dan Nias Press.

Arinanto, Satya. 2003.

"Hak Asasi Manusia dalam Transisi Politik Indonesia" Artikel tidak diterbitkan.

Fealy, Grek. 1995.

"The Release of Indonesia's Political Prisoners: Domestic Versus Foreign Policy, 1975-1979" Clayton: Working Paper, Monash University.

Krisnadi. 2000.

Tahanan Politik Pulau Buru 1969-1979. Jakarta: LP3ES.

Simon, Roger. 2004.

Gagasan-gagasan Politik Gramsci. Yogyakarta: Pustaka Pelajar. 


\section{Koran}

"Presiden Ingin Rehabilitasi dan Beri Kompensasi Tapol", Kompas, 17 Maret 2005.

Ketua Komnas HAM:

Pelanggaran Masa Lalu Diterlantarkan, Kompas, 2 Mei 2005

\section{Wawancara}

Anwar Abbas, wawancara,20 Juli dan 19 September, 2008 di Makassar Sulawesi.

Ir. Rasyidi Amra, Wawancara, 23 Agustus 2008 di MakassarSulawesi Selatan.

Muh. Tahir, wawancara, 25 Agustus 2008 di Makassar Sulawesi Selatan. 